\title{
The Nagin Parbhoo History of Anaesthesia Museum - Part 1
}

\section{PC Gordon, MFM James}

Department of Anaesthesia and Perioperative Medicine, University of Cape Town, Cape Town, South Africa Corresponding author, email:peter.gordon@uct.ac.za

This paper provides a brief history of the Nagin Parbhoo History of Anaesthesia Museum housed in the University of Cape Town Department of Anaesthesia and Perioperative Medicine and introduces readers to the contents of the museum. Artifacts are contextualised and demonstrate the vast changes that have taken place in the specialty from the early days of 'rag and bottle' anaesthesia in the 1840 s to the present. The role of a medical museum in preserving the history of the specialty, encouraging research and in using artifacts to teach physical principles relating to anaesthetic equipment is discussed. A follow-up paper will document the history of the museum.

Keywords: history of anaesthesia, anaesthetic equipment

\section{Introduction}

The Nagin Parbhoo History of Anaesthesia Museum is housed in the University of Cape Town (UCT) and Groote Schuur Hospital's Department of Anaesthesia and Perioperative Medicine. The collection started in earnest in 1956 after the donation of equipment and papers belonging to South Africa's first specialist anaesthetist, Dr Bampfylde Daniell, by Port Elizabeth anaesthetist and founder member of the South African Society of Anaesthetists (SASA), Dr Ronald A (Pom) Moore Dyk. ${ }^{1}$ The collection was initially housed in the office of the Head of Department (HOD) of the UCT Department of Anaesthesia. It moved to the expanded department facilities in the New Groote Schuur Hospital building after it opened in 1984. In 2000, Professor Michael James, the HOD of the department at that time, named the museum after its Honorary Curator, Dr Nagin Parbhoo who had expanded the museum and procured sponsorship for the installation of eight glass and oak display cabinets. ${ }^{2}$ Our present paper introduces readers to the museum and contextualises some of the artefacts.

\section{Early history of modern anaesthesia (1842-1900)}

The history of modern anaesthesia dates back to 1842 when US physician, Dr Crawford Long, first used ether to annul the pain of surgery but he did not publish his findings until $1849 .{ }^{3}$ Consequently the credit goes to Dr William Morton who gave the first successful public demonstration of etherisation to annul pain of surgery at the Massachusetts General Hospital on 16 October $1846 .{ }^{4}$ A replica of Morton's inhaler was donated to the museum by Dr George Bause, Honorary Curator of the Wood Library-Museum in Chicago and presented by Dr David Wilkinson, the President of WFSA, at a History of Anaesthesia and Ethics symposium organised by the UCT department in 2014 (Figure 1).

The news of Morton's demonstration spread rapidly around the world. In June 1847 Dr William G Atherstone in Grahamstown designed his own ether inhaler from a milk bottle and used it to administer the first anaesthetic for major surgery in Africa in June 1847. ${ }^{5} \mathrm{~A}$ facsimile of the inhaler (Figure 2 ) together with a copy of the Grahamstown Journal report of the event that appeared on 19 June 1847 are displayed in the museum.

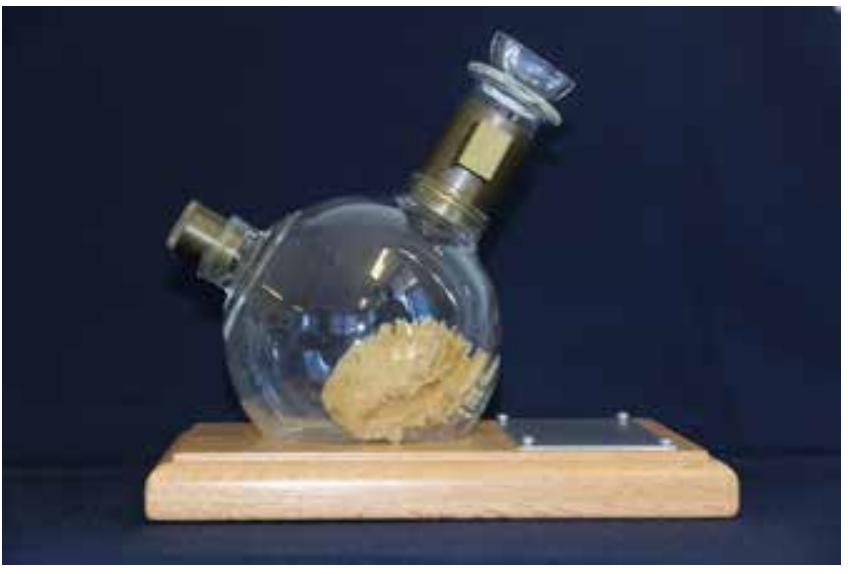

Figure 1. Morton inhaler (facsimile)

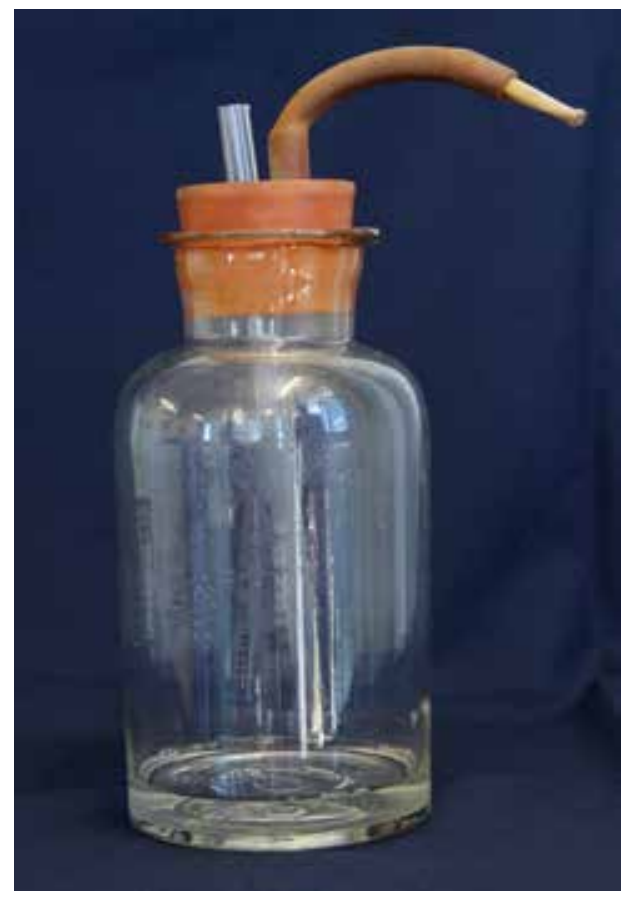

Figure 2. Atherstone inhaler (facsimile) 
Prior to the establishment of the New Somerset Hospital as the UCT and SA's first teaching hospital in 1920, South African doctors were forced to go overseas for training. Returning doctors brought back a wide variety of equipment for administering ether, chloroform, ethyl chloride and nitrous oxide. Much of that early equipment has been preserved and can be seen in the museum.

\section{Rare artefacts from that era include:}

- A chloroform inhaler designed by London gynaecologist, Dr Murphy, in 1847 to provide analgesia during labour ${ }^{6,7}$ (Figure 3).

- A wide variety of masks and drop bottles for use with chloroform or ether. The mask and chloroform drop bottle together with leather case and forceps (Figure 4) was designed in 1877 by German surgeon, Dr Johann Friedrich von Esmarch, for use on the battlefield ${ }^{8}$ and predates the more commonly known Schimmelbusch mask (c 1889) ${ }^{9}$. Esmarch's inhaler was still used during the $2^{\text {nd }}$ World War. ${ }^{10}$

- The Junkers chloroform inhaler designed in 1867 was the first to use the "blow-over" principle to deliver anaesthetic vapour. This was achieved with a hand bellows (see Figure 5). Numerous modifications were later introduced by anaesthetists to reduce the risk of misconnection that resulted in patients getting liquid chloroform blown into their lungs (Figure 5).

- One of the treasures in the museum is the first portable inhaler that allowed a convenient means of regulating the concentration of ether, designed by pioneer English anaesthetist, Dr Joseph Clover, in $1877^{11}$ (Figure 6). Clover, together with John Snow, is honoured by their presence as supporters of the shield on the coat of arms of the Royal College of Anaesthetists.

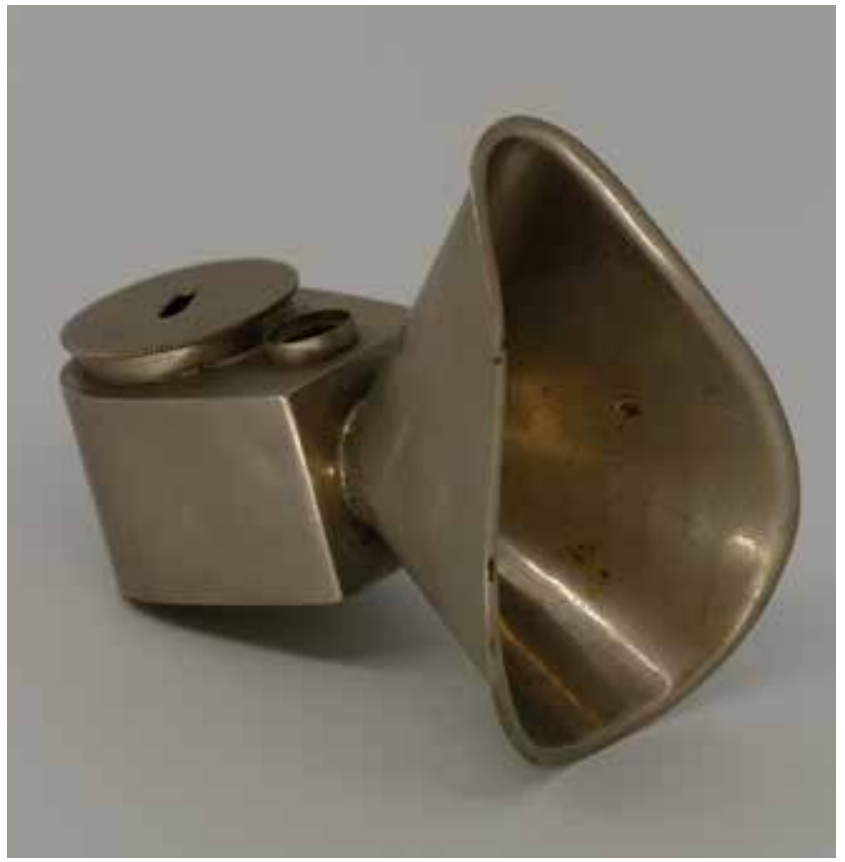

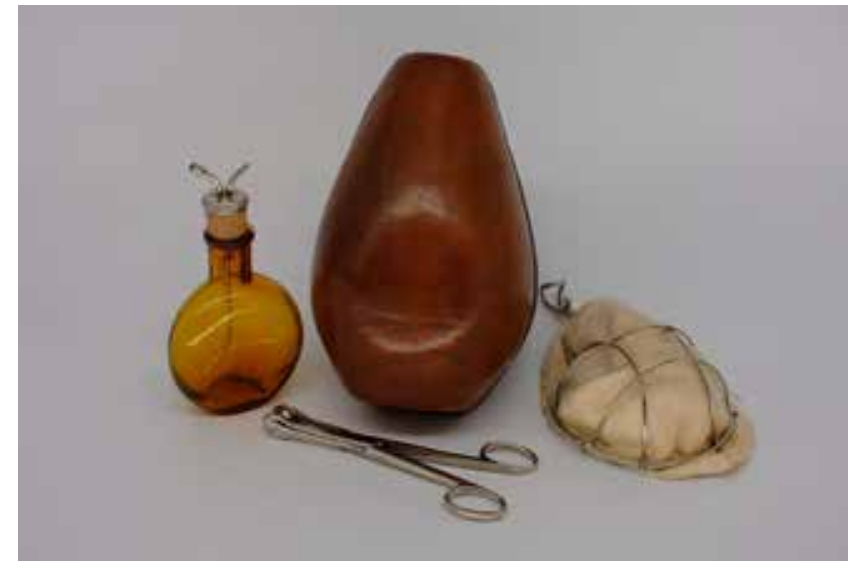

Figure 4. Esmarch chloroform mask set c 1879

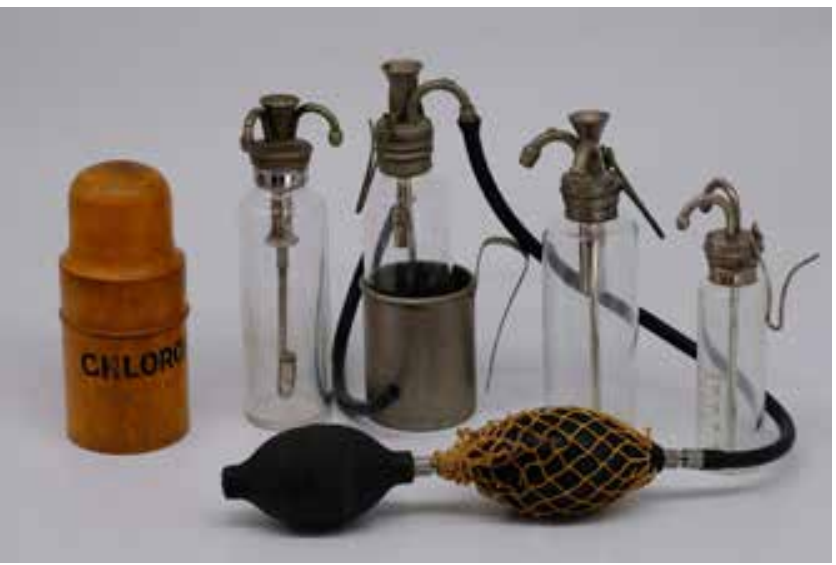

Figure 5. Junkers inhaler with hand bellows. Earliest versions on the right. Later models were modified to reduce the risk of inhalation of liquid chloroform

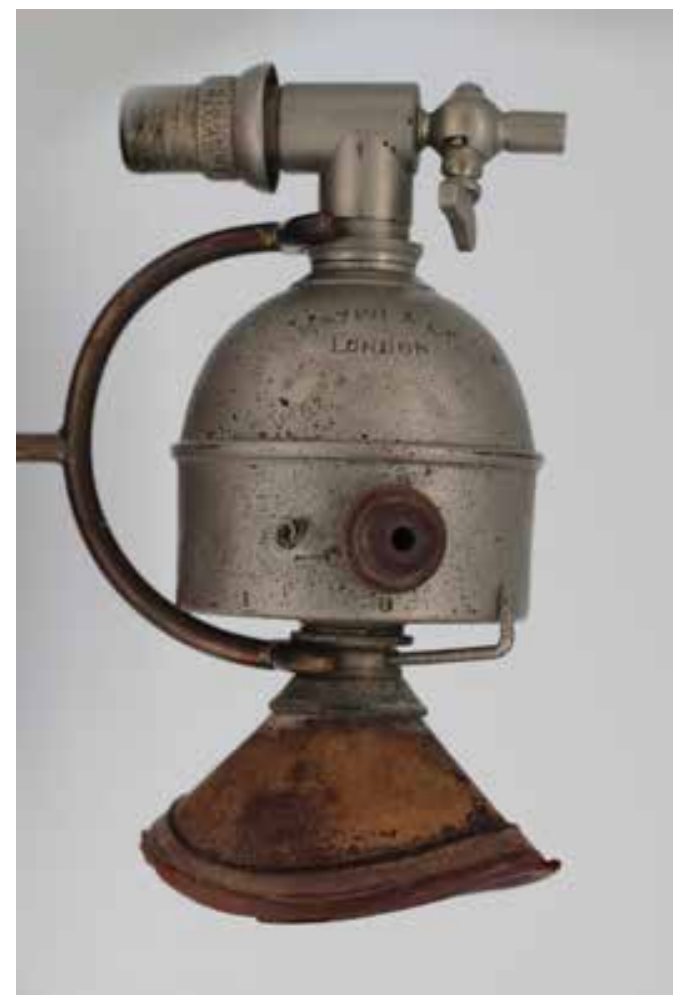




\section{0-1939}

Dr George W Bampfylde Daniell was South Africa's first "specialist anaesthetist", in that he confined his practice to the specialty. He qualified MRCS LRCP in London in 1884 and emigrated to SA in 1897. After serving as a Civil Surgeon during the Anglo-Boer War he returned to the United Kingdom (UK) to pursue his interest in anaesthesia, became a lecturer in anaesthetics at the University of Edinburgh, designed anaesthetic equipment, and then returned to SA in 1905. In 1906 he became the first anaesthetist to be appointed as an anaesthetist to the Johannesburg Hospital, a position he held until 1908 when he returned to private practice in Cape Town. ${ }^{12}$ In 1920 he was appointed as an honorary anaesthetist at the New Somerset Hospital, and in 1921, when anaesthesia was taught in the fourth year of study, he was appointed as the UCT's first lecturer in anaesthesia. ${ }^{12}$ Anaesthetic equipment in the collection from that era includes the ethyl chloride inhaler designed by Daniell ${ }^{13}$ (Figure 7), the Shipway apparatus for administering warm ether and/or chloroform (note the gold coloured heat insulator) ${ }^{14}$ (Figure 8) and an original 1917 Boyle nitrous oxide/oxygen/ether apparatus named after English anaesthetist, Dr Henry EG Boyle ${ }^{15}$ (Figure 9). The apparatus has a bubble-through water-sight flowmeter for nitrous oxide and oxygen with no flow control knobs, and an ether inhaler with no temperature compensation mechanism. Gas flows were crudely controlled by the wooden cylinder control knob that adjusted the degree to which the cylinder opened. The lack of fine control of gas flow frequently led to the high cylinder pressures rupturing the glass tubes. The spirits burner visible on the cross bar was used to heat the outflow tract of the nitrous oxide from the cylinder to prevent water vapour present as a contaminant in the nitrous oxide from freezing during use and blocking the outflow pipe of the gas with ice.

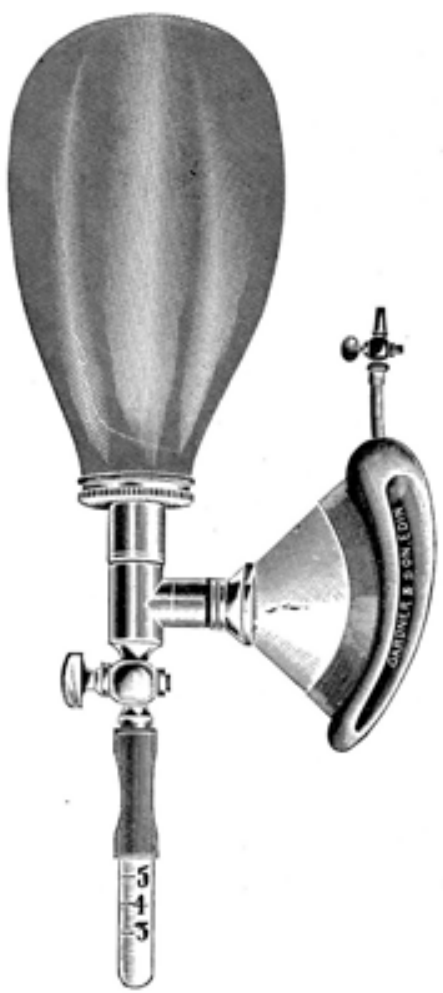

Figure 7. Daniell ethyl chloride inhaler c 1904

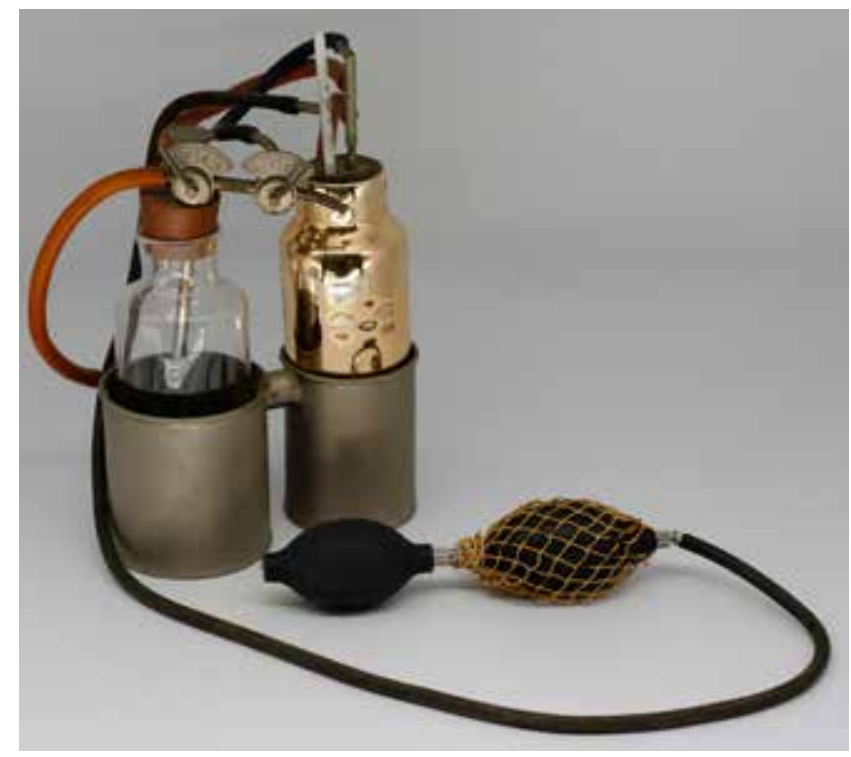

Figure 8. Shipway apparatus c 1921

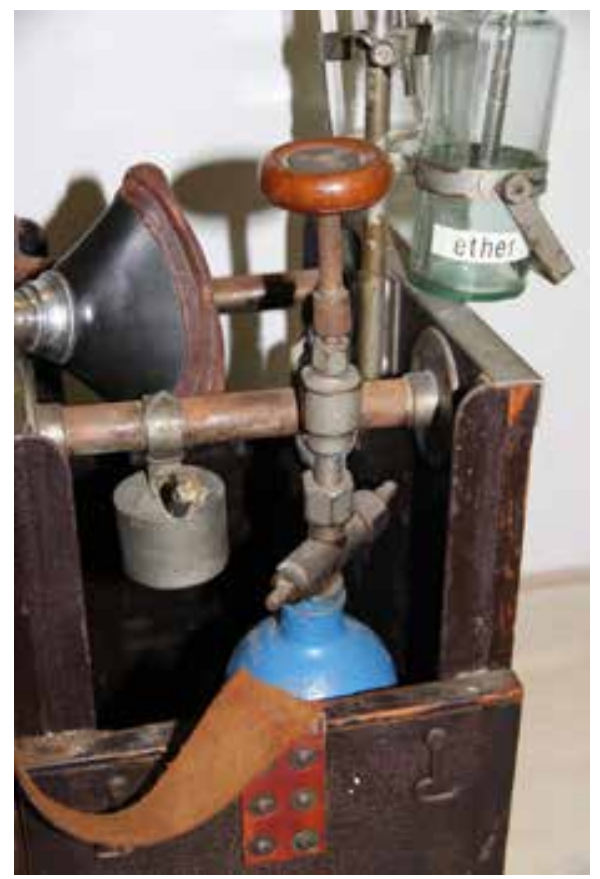

Figure 9. Boyle machine c 1917

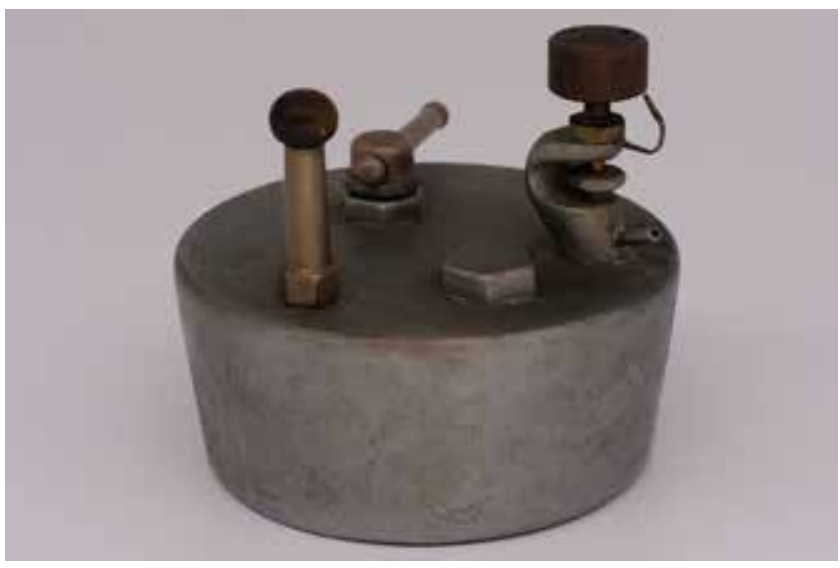

Figure 10. Pinson ether "bomb" c 1921 
New Zealand-born Dr Royden Mclntosh Muir trained in Edinburgh and emigrated to Cape Town in 1921 where he joined Bampfylde Daniell in private practice, and from 1922 as a lecturer in anaesthesia at the UCT Medical School. Muir brought with him a Pinson ether "bomb" (Figure 10) that was used for maintenance of anaesthesia after induction with Hewitt's wide-bore inhaler. ${ }^{16}$ Both items are on display. The principle behind the Pinson bomb, viz a heated, pressurised vapour chamber, is similar to that used in modern desflurane vaporisers.

The museum possesses three other early portable "Boyle machines" designed and manufactured by Coxeter and Son, London, that demonstrate major improvements in design due to advancing technology. The 1930 model was the first to use a rising, dry bobbin flow meter. ${ }^{15}$ In 1933 fine control knobs were added for the first time. A version of this machine was owned by Cape Town general practitioner anaesthetist, Dr Charles Shapiro who transported the device by horse and cart for domiciliary use, particularly for dental procedures on the Cape flats. (He later became Chris Barnard's GP).

\section{The American Influence 1920-1939}

Early South African anaesthetists travelled overseas for training and brought back equipment from the UK, Europe or the USA. Such equipment includes a portable, demand flow, gasoxygen machine designed by American anaesthesiologist, Elmar McKesson, in 1920. (Figure 11). It allowed the dangerous technique of "secondary saturation" to be performed whereby the patient would inhale $100 \%$ nitrous oxide until they became cyanosed and started jactitating (a hypoxic seizure), following which, they were given one breath of $100 \%$ oxygen and then the anaesthetic would be continued with approximately $93 \%$ nitrous oxide and $7 \%$ oxygen. ${ }^{17}$ The museum possesses two such machines - the 1920 model G, and the "improved" 1930 Nargraf J model that was used around the world for many years - particularly for dental anaesthesia (Figure12). It was the first anaesthesia machine capable of creating automated anaesthesia records. The recorder visible on the right of Figure 12 could document on paper the patient's blood pressure, percentage of oxygen delivered to the patient, rebreathed volume and respiration in the form of a tidal graph. ${ }^{18}$

In the 1930s leading South African anaesthetists travelled by sea to the USA bringing back new knowledge and equipment. They included Cape Town's Royden Muir and Eric van Hoogstraten, Benjamin Weinbren from Johannesburg and Harry Grant Whyte from Durban. During his journey in 1933, Muir became the first South African anaesthetist to present a paper at a major international congress in the USA. ${ }^{19}$ In the USA he was taught how to use cyclopropane by Professor Ralph Waters. In New York he met the equipment-maker Richard von Foregger from whom he purchased a 4-yoke anaesthetic machine for use with cyclopropane (or ether) and oxygen via a Waters to-andfro breathing system (Figures 13 and 14). On his return voyage Muir introduced cyclopropane to England and South Africa. ${ }^{20}$ At the time anaesthetists in the UK and SA worked as honorary

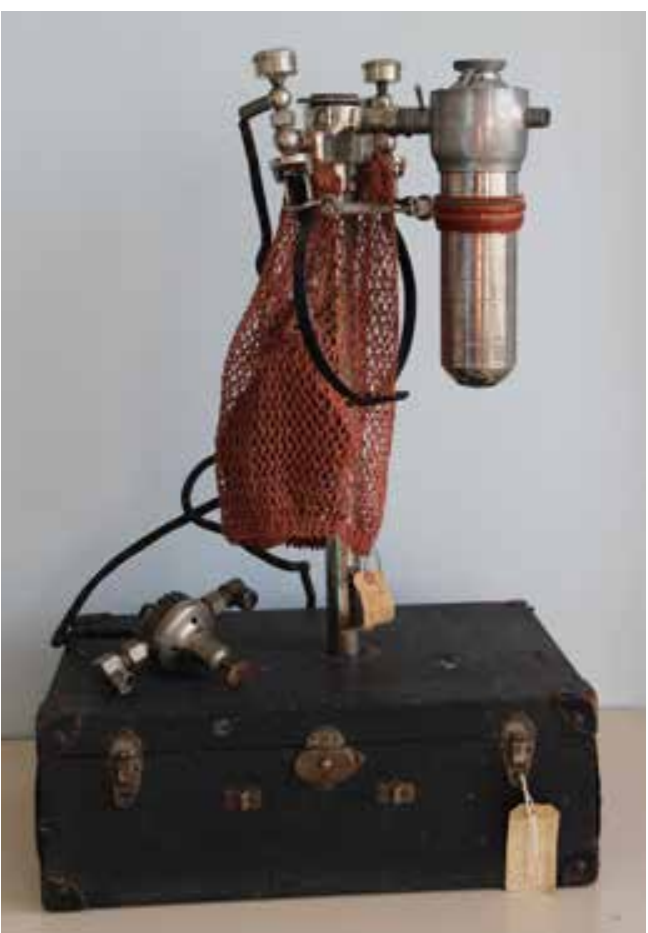

Figure 11. McKesson model G with ether vaporiser c 1920

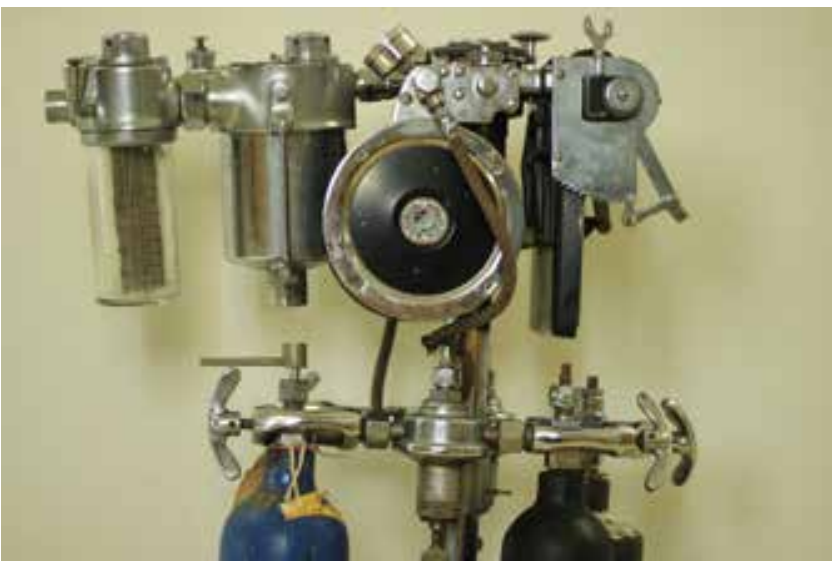

Figure 12. McKesson Nargraf model J c 1930

anaesthetists in state hospitals and received remuneration from their surgeon for work done in private practice. Private hospitals in SA only provided oxygen and anaesthetists had to carry their own anaesthetic apparatus, drugs, syringes, etc. from hospital to hospital. Muir therefore commissioned Foregger to design a unique lightweight anaesthetic machine for use with cyclopropane or ether that was advertised in the 1935 Foregger Catalogue as the "The Muir Midget - the exclusive and unique design of Dr RM MUIR of Capetown, South Africa" (Figure 15). He returned to the USA in 1938 and brought back an early "laryngeal type airway" designed by Canadian Beverly Leech in 1936 and manufactured by Foregger (Figure 16). ${ }^{21}$ All three Foregger devices mentioned above are on display in the museum. Muir was elected as SASA's second President in 1944 and in his inaugural address made a plea for SA to follow the USA and UK route and develop independent anaesthetic departments with research facilities, and improved anaesthetic training and intraoperative monitoring. ${ }^{22}$ 


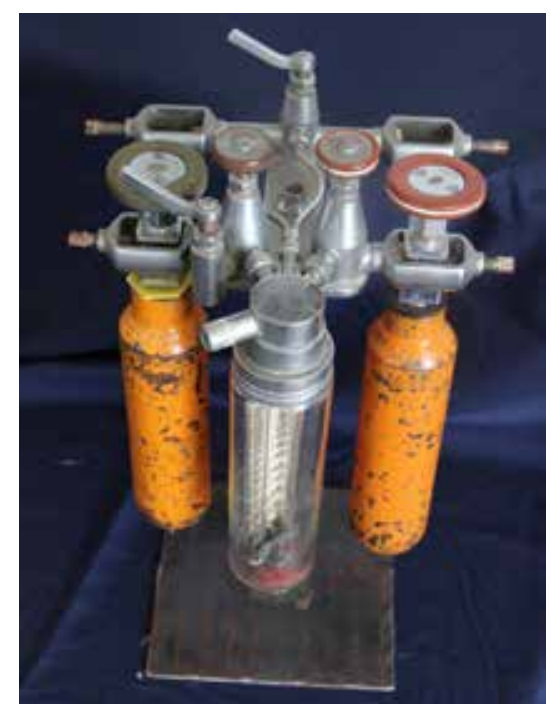

Figure 13.4-yoke Foregger Midget c 1934

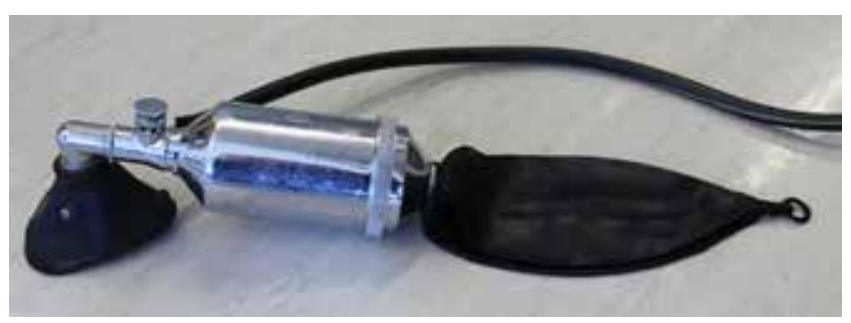

Figure 14. Waters to-and-fro cannister

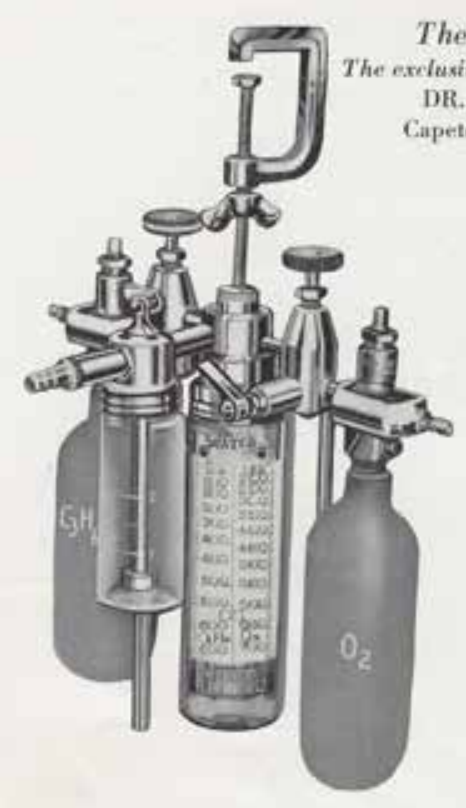

The Muir Midget (Dite and unique design of

D. M. MUIR of

petown, South Africa

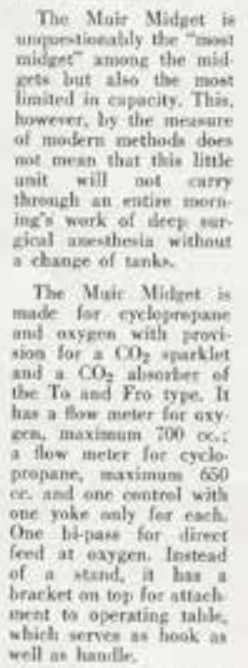

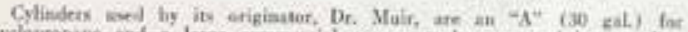
cyelopropane and a large comimercial oxyper tank comerited by couplise The special outit of De. Mair includess

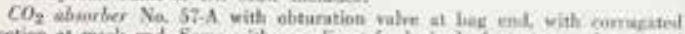

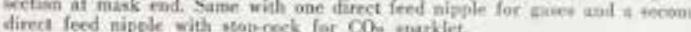
Swall Fither Alacechtiont of bubble trete.

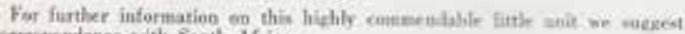
correspendence with Sosth Arrica,

Price of Meir Midert:

Nidest anly, witheut attackment?

Sinall Fther atuachiment

Obturation Yalte

Oeturation

Conocetions to lanes asyerk crith

Figure 15. The Muir Midget c 1935

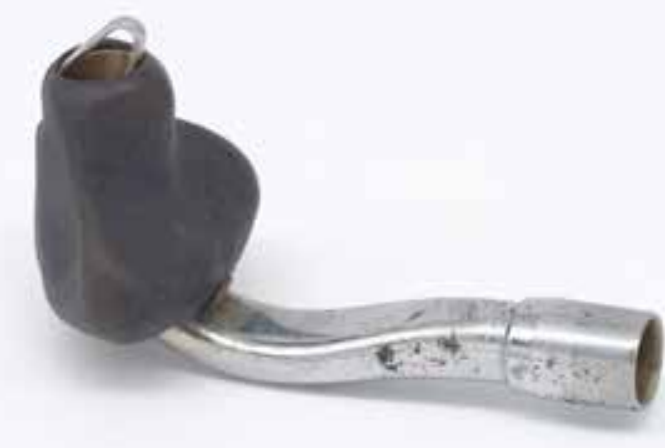

Figure 16. Leech pharyngeal gasway c 1936

\section{South African inventors of anaesthesia equipment}

The collection hosts a display of anaesthetic equipment designed by South Africans. These include: the Bampfylde Daniell ethyl chloride inhaler (c 1904) ${ }^{23}$, the Taurus blood warmer named after Professor Arthur Bull (Figure 17), ${ }^{24}$ the Cape Town paediatric circuit, ${ }^{25}$ Samson's neonatal resuscitator (c 1966) and his improved resuscitator with an accordion-like bellows (c 1974) (Figure 18), ${ }^{26,27}$ and his modification of the Water's canister, ${ }^{28}$ and breathing circuits designed by Samson, ${ }^{28,29}$ Miller $^{30}$ and Humphrey. ${ }^{31}$

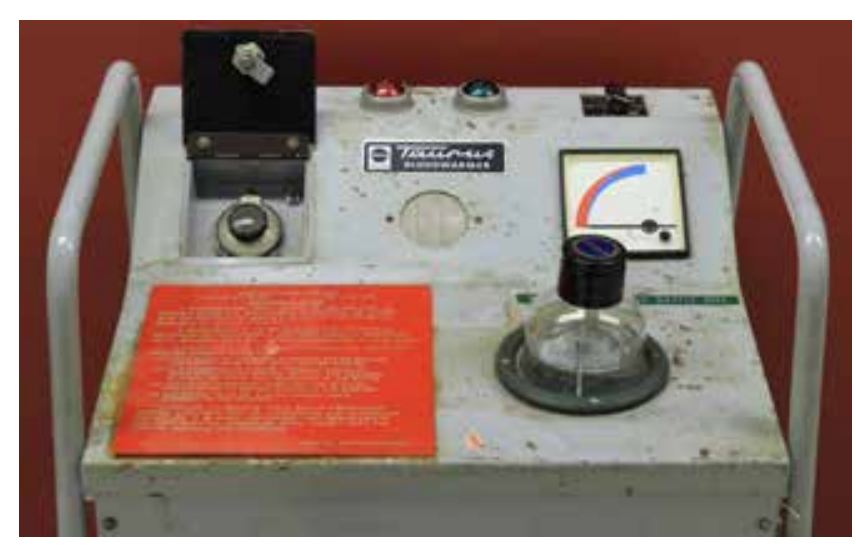

Figure 17. Taurus blood warmer Mark II c1972

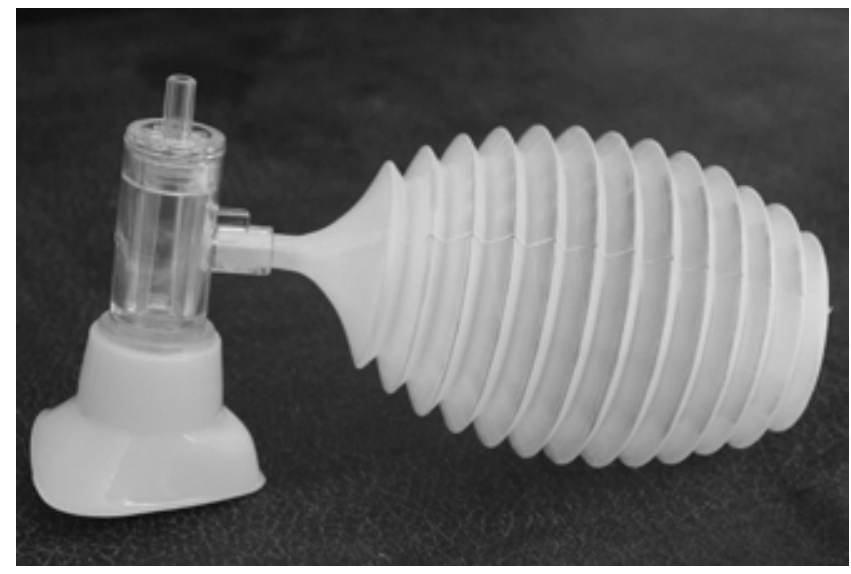

Figure 18. Samson neonatal resuscitator c 1974 


\section{Ventilators}

The collection possesses a wide variety of ventilators ranging from the tiny hand-sized ventilator designed by Johannesburg anaesthetist, Dr Anthony Cohen, in 1965 and marketed as the Minivent (Figure 19) ${ }^{32}$ - to a 620 kg Dräger E52 iron lung designed in the 1950s to treat patients in the polio epidemics of that era (Figure 20). After IPPV ventilators replaced the iron lung for the treatment of polio victims with respiratory insufficiency, the Groote Schuur Draeger iron lung was used purely for transporting patients with ventilatory insufficiency. The prototype of the Draeger iron lung was designed in $1947 .{ }^{33}$ Cohen's Minivent was born out of the requirement for anaesthetists in private practice in the 1960 s to carry equipment from hospital to hospital.

Other ventilators on display include the Oxford Inflating Bellows, $^{34}$ the iconic Manley ventilator ${ }^{35}$ and a wide range of Bird ${ }^{\circ}$ ventilators designed by aeronautical engineer Forest Bird that were used in intensive care units and operating theatres around the world. The Bird ${ }^{\circ}$ Mk 7 was modified for use in theatres at Groote Schuur and Red Cross War Memorial Children's hospitals by DrTom Voss, using a dead-space known as the "elephant tube", to separate driving gas powering the ventilator from anaesthetic gases. ${ }^{36}$

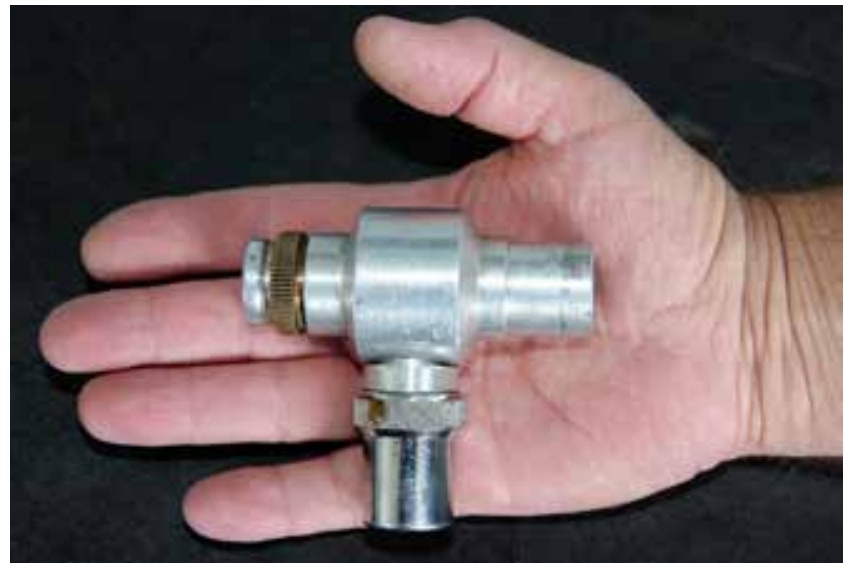

Figure 19. Minivent ventilator c 1965

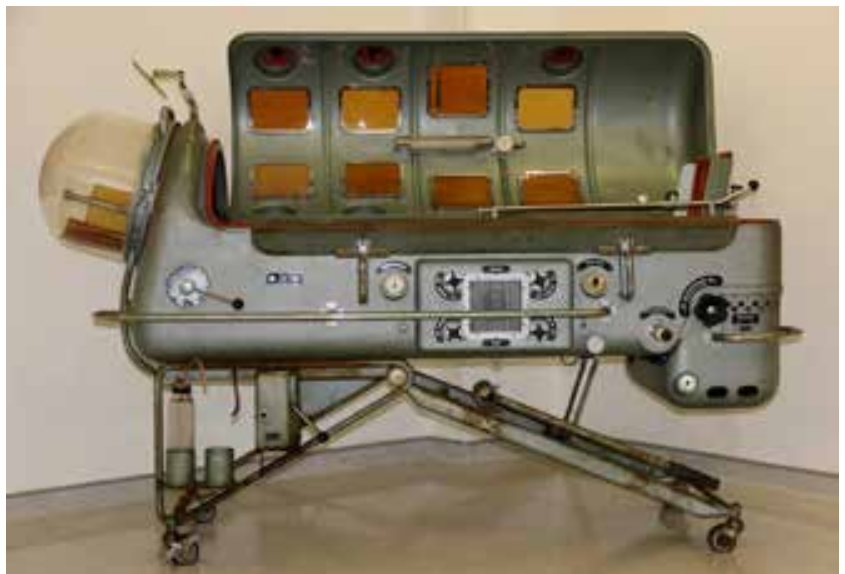

Figure 20. The Dräger iron lung c 1955

\section{Monitors}

Items in the collection allow visitors to explore the vast changes in monitoring since 1846 and more recently post WW2. Artefacts include Marey's sphygmometer (c 1860), the first device to conveniently record the pulse wave (Figure 21);37 the water manometer first used to measure central venous and arterial blood pressure at Groote Schuur and Red Cross Children's Hospitals in the 1960s (Figure 22); the Van Slyke apparatus used to estimate blood carbon dioxide after the outbreak of polio in Copenhagen in $1953 ;{ }^{38}$ the BOC colorimetric carbon dioxide analyser (Figure 23) seen attached to the inspiratory limb of a Gillies Mark 3 apparatus; the Astrup machine used to measure blood gases during the first heart transplant, and the Dräger Narkotest, ${ }^{39}$ an early agent monitor that measured halothane concentrations by changes in length of silicone rubber bands produced by varying concentration of the agent. Early machine monitors on display include the Bosun whistle developed by BOC in the $1960 s^{40}$ and the Ritchie whistle developed in the 1970 s, to warn of oxygen supply failure.

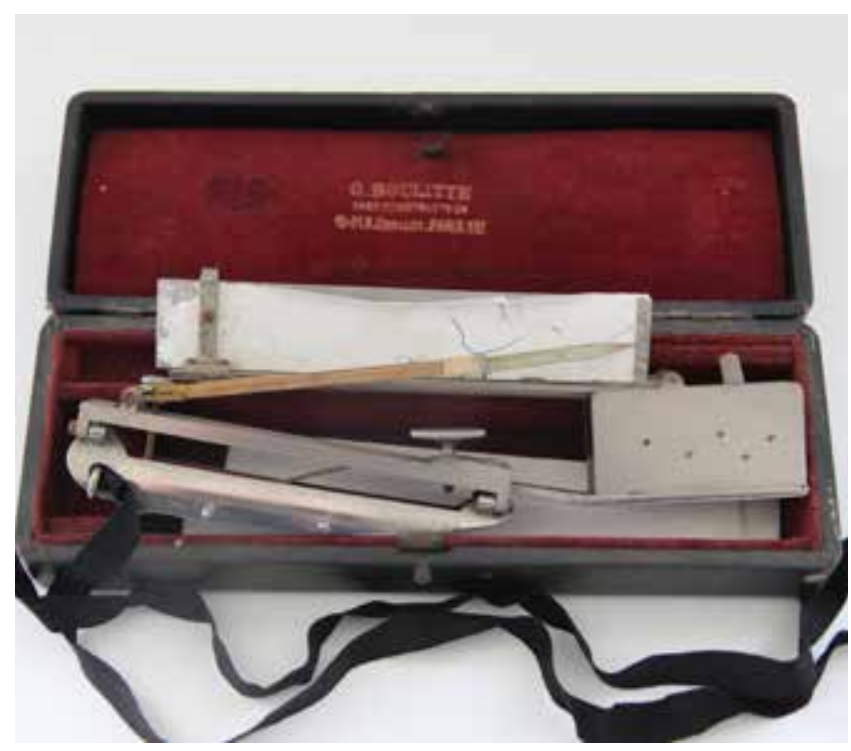

Figure 21a. Marey's sphygmograph for graphically recording the pulse wave c 1860

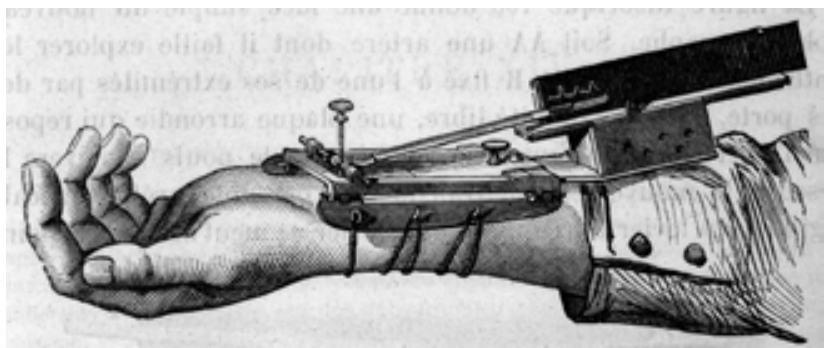

Figure 21 b. Marey sphygmograph (image courtesy of Welcome Collection)

https://iiif.wellcomecollection.org/image/L0012232.jpg/full/full/0/ default.jpg 


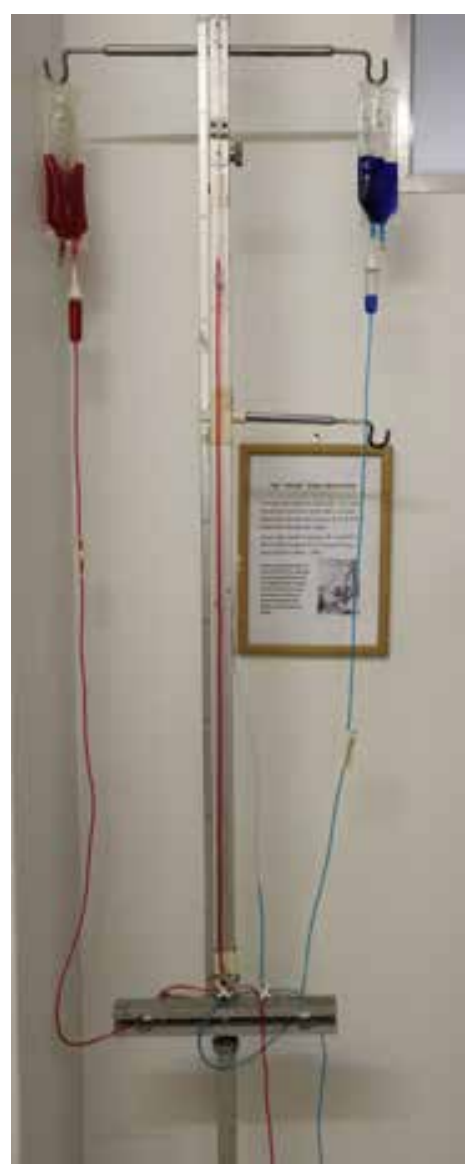

Figure 22. (Left) Water manometer for measuring arterial and central venous pressures

Figure 23. (Below) BOC colorimetric $\mathrm{CO}_{2}$ analyser attached to Gillies anaesthetic machine

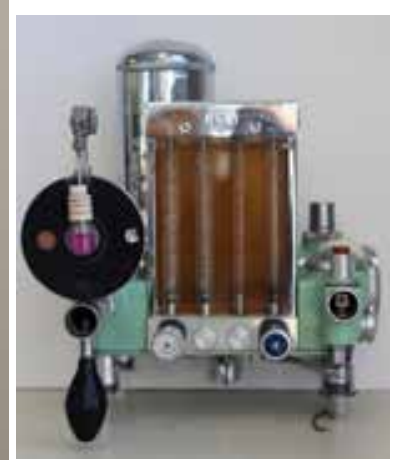

\section{Pharmaceuticals}

The museum has a cabinet displaying the evolution of drugs used in anaesthesia from ether, chloroform and cyclopropane, to propofol and desflurane. Unusual drugs on display include:

- ampoules of spinocaine that were popularised by Pitkin for spinal anaesthesia that contain novacaine mixed with strychnine dissolved in $14.5 \%$ alcohol, rendering it dangerously hypobaric $^{41}$ (Figure 24)

- rectal suppositories of thiopentone for basal sedation in infants and children ${ }^{42}$ (Figure 25)

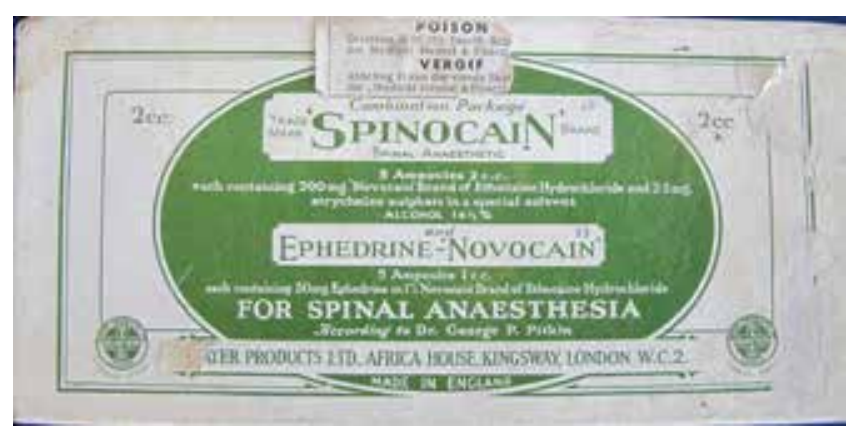

Figure 24. Spinocaine c 1928

\section{The UCT Department of Anaesthesia and Perioperative Medicine ${ }^{43}$}

The UCT Department is the oldest anaesthetic department in South Africa with its first lecturers being appointed when anaesthesia was first taught as a subject in 1921. The history of

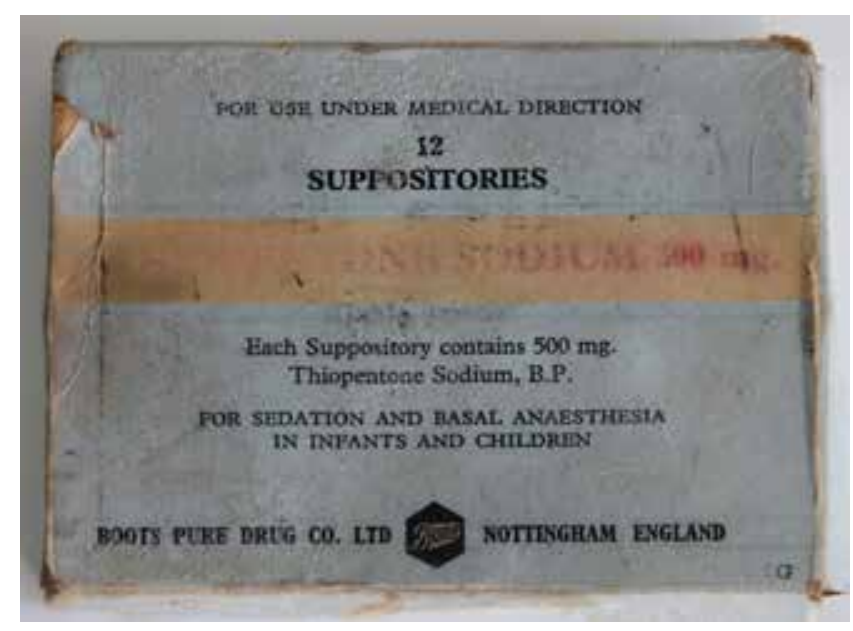

Figure 25. Thiopentone suppositories c 1958

the department is recorded in photographs of many of the early anaesthetists and all previous Heads of the Department. Posters honouring Professor Gaisford Harrison for his seminal research into the incidence and causes of anaesthetic-related mortality, and his later work on malignant hyperthermia, and Professor Joseph Ozinsky's role in establishing a world class cardiothoracic anaesthesia department that played a major role in enabling Professor Barnard to perform the world's first human-to-human heart transplant operation. ${ }^{44}$

Attempts were made to house the museum in the UCT Medical Library, but this was not feasible. As the departmental space was expanded to include the Anglo-American laboratory and offices, the museum exhibits were placed in the office of the HOD, but this was unsatisfactory as access to the collection was minimal. With the establishment of the new department, physical space in D23 of New Groote Schuur Hospital, and the further expansion of the departmental footprint, there was now adequate space for a proper formal museum display in its present location.

Academic honours boards recording recipients from the department that have won medals in the College of Anaesthetists of the Colleges of Medicine of South Africa examinations, or awarded prizes for excellence are present.

\section{The South African Society of Anaesthesiologists (SASA)}

A section of the museum is devoted to the history of the Society. It includes photographs of founder members attending the inaugural meeting in 1943 (Figure 26); delegates attending the 1955 World Congress of Anaesthesiology at which South Africa became a founder member of the World Federation of Societies of Anaesthesiologists, and many of the international speakers that have visited South Africa at the invitation of the Society. Practice and other Guidelines developed by the Society are displayed together with gifts to SASA from international bodies. A separate display commemorates the holding in Cape Town of the very successful 2008 World Congress of Anaesthesiologists organised by the Society. 


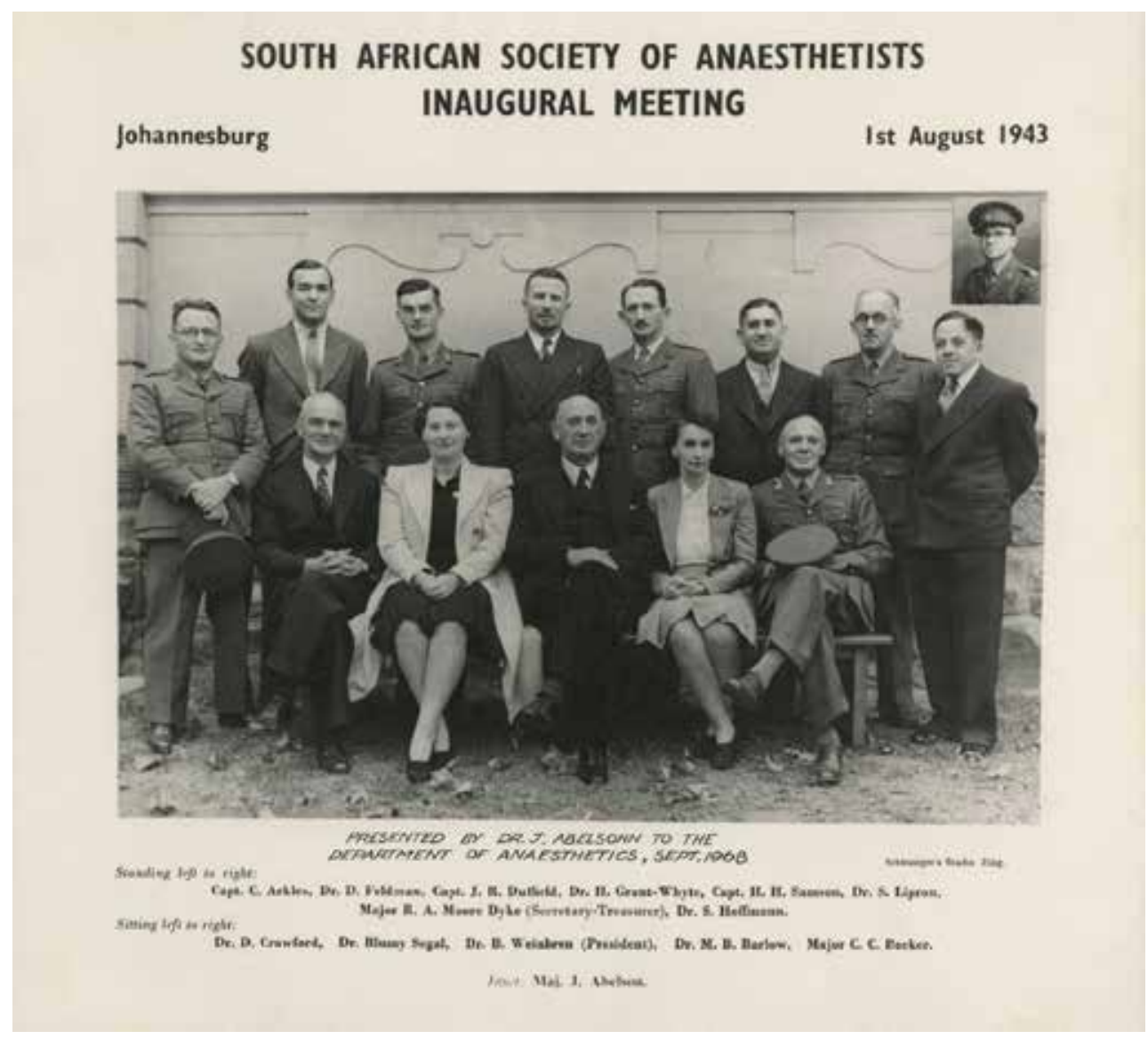

Figure 26. Delegates to the inaugural meeting of the SA Society of Anaesthetists, 1943
The museum provides a fertile ground for individuals interested in medical history. Several publications have emanated from the museum. These include papers on Bampfylde Daniell, ${ }^{12}$ Royden Muir, ${ }^{20}$ Arthur Bull and the Taurus Blood Warmer, ${ }^{46}$ Hymie Samson, ${ }^{29}$ Tom Voss, ${ }^{36}$ Tony Cohen and the Minivent ventilator, ${ }^{47}$ the artist Dorothy Kay, ${ }^{48}$ and Joseph Ozinsky and his role in the world's first human-to-human heart transplant operation, ${ }^{49,50}$ and books documenting the history of the SA Society of Anaesthesiologists. ${ }^{51,52}$

\section{Quo Vadis?}

The collection is unique in Africa and probably the second best in the Southern Hemisphere after the very impressive State sponsored Geoffrey Kaye Museum in Melbourne. Because the museum is housed in a busy department, access to visitors is by appointment. It is hoped

\section{The role of an anaesthetic museum in 2019}

The role of the museum can be summarised as follows:

- To preserve artefacts reflecting the history of a specialty that has grown from being an ancillary department of surgery to one that now encompasses anaesthesia, critical care, perioperative medicine, and the treatment of acute and chronic pain. ${ }^{45}$

- To record the ongoing history of:

- Anaesthesia and its related subspecialties since 1846.

- The SA Society of Anaesthesiologists from its humble beginnings in 1943 to one with over 2000 members in 2019.

- The UCT Department of Anaesthesia from its beginnings in 1920 to the present. ${ }^{43}$

- To document the contribution of South African anaesthetists to the design of anaesthesia-related equipment.

- Teaching

Artefacts from the museum have proved invaluable in explaining physical principles related to the design of anaesthetic and monitoring equipment to registrars and medical officers in training. During their anaesthetic block, fourth year medical students are shown the Draeger iron lung in the collection and asked to reflect on the management of polio during the Copenhagen epidemic of 1952 and how it led to the formation of multidisciplinary intensive care units around the world.

- Research that in the future funding can be found to make the collection available to researchers, scholars and visitors, on line. This will hopefully include recording oral histories of leading figures in anaesthesia, critical care and pain management.

Contacts with international and national medical historians need to be developed. With this in mind the department plans to host a $2^{\text {nd }}$ International Symposium, on History of Anaesthesia and Critical Care in 2021.

\section{Acknowledgements:}

Thanks to Dr Etienne Coetzee and Mr Lance Howell for assistance in photographing items in the museum.

This paper highlighting the collection will be followed by a paper chronicling the history of the museum.

\section{References}

1. Jones CS. Letter to UCT Library. 1956

2. Parbhoo NP. The Department of Anaesthesia, UCT 1920 - 2000 - A History. Department of Anaesthesia. Cape Town: University of Cape Town, 2000;282-3.

3. Long CW. An account of the first use of sulphuric ether by inhalation as an anaesthetic in surgical operations. Southern Medical and Surgical Journal 1849;5:705-13.

4. Bigelow $\mathrm{H}$. Insensibility during surgical operations produced by inhalation Boston Med Surg J 1846;35:309-17.

5. Atherstone WG. Reminiscences of medical practice in South Africa fifty years ago. S Afr Med J 1897;1:243-7.

6. Murphy EW. Chloroform in the practice of widwifery. London: Harveian Society, 1848.

7. Bause GS. Murphy chloroform inhaler. Anesthesiology 1847;113:778. DOI: 10.1097/ALN.0b013e3181fac15. 
8. Esmarch Inhaler. https://www.woodlibrarymuseum.org/museum/item/115/ esmarch-inhaler; (Accessed June 2019).

9. Duncum BM. The Development of Inhalational Anaesthesia. London: Oxford University Press, 1947.

10. Kaye G. Manual of Army Anaesthetic Apparatus. Melbourne: Australian Military Forces, 1942.

11. Clover JT. Portable Regulating Ether-Inhaler. Br Med J 1877;1:69-70. DOI: 10.1136/bmj.1.838.69.

12. Parbhoo NP. George Warwick Bampfylde Daniell, 1864-1937. S Afr Med J 1987;71.

13. Daniell GWB. A simple of administering chloride of ethyl and Somnifor alone or in conjunction with nitrous oxide or ether; and a new method for their administration. Br Med J 1904

14. Thomas KB. The Development of Anaesthetic Apparatus. Oxford: Blackwell Scientific Publications, 1975.

15. Watt OM. The evolution of the Boyle apparatus, 1917-67. Anaesthesia 1968;23:103-18. DOI: 10.1111/j.1365-2044.1968.tb00015.x.

16. Louw JH. In the Shadow of Table Mountain A history of the University of Cape Town Medical School. Cape Town: Struik Publishers, 1969.

17. McKesson El. Gas-and-oxygen anaesthesia in abdominal surgery; and "secondary saturation". Proc R Soc Med 1926;19:57-64.

18. McKesson-Nargraff Model J. https://www.woodlibrarymuseum.org/museum/ record.php?itemID=84.

19. Muir RM. The routine life and work of an anesthetist in Cape Town.*. Anesth Analg 1934;13:51-5.

20. Gordon PC. Royden McIntosh Muir and His Anesthetic Links Between South Africa, London, and the United States. J Anesth Hist 2016;2:89-95. DOl: 10.1016/j. janh.2016.05.004.

21. Leech BC. The Pharyngeal Bulb Gasway: A New Aid in Cyclopropane Anesthesia.* Anesth Analg 1937;16:22-5.

22. Muir RM. On the teaching of anaesthesia*. S Afr Med J 1920;18:343-5.

23. Daniell GW. On the administration of chloride of ethyl and somnoform, alone or in conjunction with nitrous oxide or ether. Br Med J 1904;1:949-50. DOI: 10.1136/ bmj.1.2260.949.

24. Besseling JL, Bull AB, Duplessis JM, Mason IM. The rapid warming of blood for massive transfusion by radio frequency induction. S Afr Med J 1965;39:137-40.

25. Voss TJ. Deadspace in Paediatric Anaesthetic Apparatus. $\mathrm{Br} J$ Anaesth 1963;35:454-9. DOI: 10.1093/bja/35.8.454.

26. Samson HH. Anaesthetic Equipment for the First 6 Months of Life. S Afr Med J 1965;39:330-1.

27. Samson HH. Resuscitation of the newborn. An improved neonatal resuscitator. $\mathrm{S}$ Afr Med J 1974;48:628-30.

28. Samson HH, Moyes DG. Valveless anaesthetic circuits incorporating scavenging. S Afr Med J 1980;57:955-8.

29. Gordon PC, Nieuwveld RW. Pioneers in South African Anaesthesia: Dr Heyman Harold (Heymie) Samson, anaesthetic innovator. South Afr J Anaesth Analg 2014;20:10-2.
30. Miller DM, Miller JC. Enclosed afferent reservoir breathing systems. Description and clinical evaluation. Br J Anaesth 1988;60:469-75. DOI: 10.1093/bja/60.4.469.

31. Humphrey D. A new anaesthetic breathing system combining Mapleson A, D and $E$ principles. A simple apparatus for low flow universal use without carbon dioxide absorption. Anaesthesia 1983;38:361-72.

32. Cohen AD. The Minivent respirator. Anaesthesia 1966;21:563-8.

33. The Dräger Iron Lung. https://twitter.com/DraegerNews/status/57854626429 7603072; (Accessed 22 June 2019).

34. Macintosh RR. Oxford inflating bellows. Br Med J 1953;2:202.

35. Manley RW. A new mechanical ventilator. Anaesthesia 1961;16:317-23.

36. Hofmeyr R, Gordon PC. Pioneers in South African Anaesthesia: Thomas Voss and the "Elephant Tube". . South Afr J Anaesth Analg 2013;19:239-41.

37. Marey Sphygmograph. https://www.woodlibrarymuseum.org/museum/ item/667/marey-sphygmograph; (Accessed 22 June 2019).

38. Van Slyke DD, Neill JM. The determination of gases in blood and other solutions by vacuum extraction and manometric measurement. I. Journal of Biological Chemistry 1924;61:523-73.

39. White DC, Wardley-Smith B. The "narkotest" anaesthetic gas meter. Br J Anaesth 1972;44:1100-4. DOI: 10.1093/bja/44.10.1100.

40. Bosun Whistle. https://ehive.com/collections/4493/objects/152721/ bosun-whistle;

41. Pitkin GP. Controllable spinal anaesthesia, "Spinocaine.": (Metz.). Br J Anaesth 1928;6:22. DOl: https://doi.org/10.1093/bja/6.1.22.

42. Aladjemoff L, Kaplan I, Gestesh T. Sodium thiopentone suppositories in paediatric anaesthesia. Anaesthesia 1958;13:152-6.

43. Thomas JM, Reed AR, Reed AR, et al. Anaesthesia - what has the University of Cape Town contributed? S Afr Med J 2012;102:415-8.

44. Ozinsky J. Cardiac transplantation--the anaesthetist's view: a case report. S Afr Med J 1967;41:1268-70.

45. Gordon PC. The Role and Purpose of Anesthesia Museums in Preserving our Heritage. J Anesth Hist 2015;1:34-5. DOI: 10.1016/j.janh.2015.02.008.

46. Gordon PC, Hauser ND, Marais J. Professor Arthur Bull and the Taurus Blood Warmer. South Afr J Anaesth Analg 2013;19:194-5.

47. Howell LC, Gordon PC. The amazing Minivent Ventilator. South Afr J Anaesth Analg 2016;22:57-9.

48. Gordon PC, Reed AR. Surgery and anaesthesia in art. The contribution of Dorothy Kay. S Afr Med J 2014;104:107-9.

49. Gordon PC, Brink JG. Forty years on: the anesthetic for the world's first human-to-human heart transplant remembered. J Cardiothorac Vasc Anesth 2008;22:133-8. DOI: 10.1053/j.jvca.2007.10.019.

50. Swanevelder JLC, Gordon PC, Brink JG, Gutsche JT, Dyer RA, Augoustides JG. Fifty Years: Reflections Since the First Successful Heart Transplant. J Cardiothorac Vasc Anesth 2018;32:14-8. DOI: 10.1053/j.jvca.2017.10.028.

51. Parbhoo NP. Five Decades, the South African Society of Anaesthetists 1943-1993. Cape Town: National Book Printers, 1993.

52. Gordon PC, Fourie P. SASA 75 Years 1993-2018. 2018 